\title{
A BETEGSZEREP FELÉRTÉKKELŐDÉSE A 21. SZÁZADI EGÉSZSÉGÜGYI ELLÁTÁSBAN: ÖNGONDOSKODÁS TÁMOGATÁSA, EGÉSZSÉG-MAGATARTÁS FEJLESZTÉSE KOMPLEX ELLÁTÁSI RENDSZERBEN
}

\author{
INCREASING ROLE OF PATIENTS IN HEALTH CARE \\ OF THE $21^{\text {ST }}$ CENTURY: \\ PROMOTING SELF-CARE, DEVELOPING HEALTH BEHAVIORS \\ IN A COMPLEX CARE SYSTEM
}

\author{
Kósa István ${ }^{1}$, Kincses Gyula ${ }^{2}$, Soós Gyöngyvér ${ }^{3}$, Grózli Csaba $^{4}$, Hohmann Judit ${ }^{5}$ \\ ${ }^{1} \mathrm{PhD}$, habilitált egyetemi docens, Szegedi Tudományegyetem Általános Orvostudományi Kar Preventív Medicina Tanszék, Szeged \\ kosa.istvan@med.u-szeged.hu \\ 2 egészégpolitikus, az MTA Elnöki bizottság az egészségért tagja \\ 3 professor emerita, Szegedi Tudományegyetem Gyógyszerésztudományi Kar Klinikai Gyógyszerészeti Intézet, Szeged \\ 4stratégiai és orvosigazgató, Magyar Szervátültetettek Szövetsége, Budapest \\ 5 az MTA levelező tagja, tanszékvezető egyetemi tanár, Szegedi Tudományegyetem, \\ Gyógyszerésztudományi Kar Farmakognóziai Intézet, Szeged
}

\begin{abstract}
ÖSSZEFOGLALÁS
A 21. századi egészségügy fenntartható fejlődéséhez paradigmaváltás szükséges az orvoslásban és az orvos-beteg kapcsolatban. A várható élettartam emelkedésével, a krónikus betegek arányának növekedésével az egészségügyi költségek oly mértékben emelkednek, amellyel a társadalmi ráfordítások nem tudnak lépést tartani. Az ellátás csak új típusú ellátási rendszerekben valósítható meg, amelyeknek lényeges új eleme a betegek aktív bevonása a gyógyítás folyamatába. A passzív betegszerepen alapuló orvos-beteg kapcsolatot a kölcsönösségen, partnerségen alapuló viszonynak kell felváltania, melyben a beteg aktív szerepet játszik saját egészségének és betegségének menedzselésében. Ezen betegszerep kialakításához megfelelően tájékozott, egészségéért felelősséget érző egyénekre és ezen készségek kialakításáért felelős egészségügyi ellátó rendszerre van szükség. Az egészségértés fejlesztését az iskolákban kell elindítani, majd az élethosszig tartó tanulás részévé kell tenni. A krónikus betegségekben szenvedők növekvő ellátási igényének kezelésére speciális öngondoskodást támogató rendszerek életre hívása szükséges. Ilyen típusú rendszerkezdemények szakmai törekvések alapján hazánkban jelenleg is léteznek egy-egy betegcsoportra kiterjedően, azonban ezen megoldások összehangolatlanok, nem integrálódnak az ellátó struktúrába, működésük finanszírozása nem megoldott. A betegek öngondoskodásának erősítése érdekében hazánkban is egy egységes keretrendszert kell kiépíteni, mely megteremti a betegek befogadóképességéhez igazított betegedukáció feltételeit, kialakítja a krónikus betegségekben jellemzően nem nélkülözhető életmódváltás támogatásának
\end{abstract}


hatásos technikáit. Az öngondoskodás megteremtésében felértékelődik a betegszervezetek és a nem orvosi diplomás egészségügyi szakemberek - gyógyszerészek, MSC/BSC-diplomás ápolók, dietetikusok, gyógytornászok - tevékenysége. A rohamosan fejlődő infokommunikációs technológiák korában súlypontilag kell építeni az életmódnak, a fiziológiai paramétereknek a beteg otthonában történő monitorozására, az ezen adatokra épülő intelligens döntéstámogató megoldások alkalmazására, illetve válogatott esetekben távkonzultációs lehetőségek kihasználására.

\section{ABSTRACT}

The sustainable development of healthcare in the $21^{\text {st }}$ century requires a paradigm shift in medicine and in doctor-patient relationships. As life expectancy rises, and the proportion of chronic patients increases, health-costs rise to the extent that social spending cannot keep with. Healthcare can only be achieved through new types of care systems, an important new element of which is the active involvement of patients in the healing process. The physician-patient relationship based on the passive role of the patient should be replaced by a relationship based on reciprocity and partnership, in which the patient plays an active role in managing his or her health and illness. Developing this role of patients requires well-informed individuals with health responsibilities and a health care system responsible for evolving these skills. Health literacy development needs to be started in schools and then integrated into lifelong learning. Special self-care support systems need to be put in place to address the growing need for care of people with chronic illnesses. Based on professional aspirations, initiatives for operable systems exist in Hungary for some group of patients at present, however, these solutions are not coordinated and not integrated into the healthcare structure, and financing their costs is not solved. To strengthen the self-care of patients, a unified framework must also be established in Hungary, which creates the conditions for patient education tailored to the capacity and skills of patients. Development of effective techniques is needed for supporting lifestyle changes that are typically essential in chronic diseases. The activities of patient organizations and non-medical graduate health professionals - such as pharmacists, graduate nurses, dieticians, physiotherapists - are highly valued in establishing self-care. In the age of rapidly evolving info-communication technologies, we must focus on monitoring lifestyle and physiological parameters in the patient's home, applying intelligent decision-support solutions based on these data, and utilizing remote consultation options in selected cases.

Kulcsszavak: öngondoskodás, egészségértés, betegedukáció, betegszervezetek, gyógyszerészi gondozás

Keywords: self-management, health literacy, patient education, patient organizations, pharmaceutical care

\section{BEVEZETÉS}

Korunk egészségügyének legnagyobb kihívása az orvosi ismeretek, orvosi technológiák robbanásszerü fejlődése kapcsán kialakuló drasztikus forrásigény-növekedés, amely komoly feszültségeket kelt a társadalmak számára még elvi- 
selhető forrásallokációs szint kialakításakor is. A technológia fejlődése mellett fontos tényező a forrásigény-bővülésben az ellátást igénybevevők körének folyamatos bővülése, elsősorban az idős, krónikus betegségekben szenvedők arányának növekedésével, de szintén bővíti az ellátotti kört az egyre kiterjedtebben végzett szűrővizsgálatok keretében kiszűrt, korábban ellátás nélkül maradt betegtömegek ellátási körbe kerülése. A forrásigény-bővülés természetesen a humánerőforrás relatív hiányával is társul. Az igények és gazdasági lehetőségek diszkrepanciáját a fejlett világ társadalmai új egészségügyi ellátási modellekkel igyekeznek egyensúlyba hozni, melynek egyik fontos eleme a betegszerep átformálása.

Ezen kihívások új feladatok elé állítják a hazai egészségügyi döntéshozókat is. Az új megoldások között feltétlenül helyet kell hogy kapjon az egyének egészségaktivitásának és önállóságának javítása, a gyógyítási tér tudatos kibővítése a betegek irányába. A betegek bevonása a betegség kezelésébe javítja az ellátás hatékonyságát, minőségét és finanszírozhatóságát.

\section{AZ ÖNGONDOSKODÁS FOGALMA ÉS FŐBB ELEMEI}

A WHO (World Health Organization) meghatározása szerint az öngondoskodás az egyén, a család, a közösségek azon képessége, mellyel elősegítik egészségük megőrzését, a betegség megelőzését, valamint menedzselik a betegséget, a megrokkant állapotot az egészségügyi szolgáltatások igénybevételével vagy anélkül. Szélesebb értelemben az öngondoskodás magában foglalja az általános és személyi higiénia, az egészséges táplálkozás, az ételvitel (sport, fizikai aktivitás), a környezeti (életkörülmények, szociális helyzet) és szocio-ökonómiai tényezők (jövedelmi viszonyok, kulturális közeg) aspektusait is. Az öngondoskodásnak három fő dimenzióját különböztetjük meg: családi, pénzügyi és egészségügyi öngondoskodás.

\subsection{Családi öngondoskodás}

Az öngondoskodás legstabilabb, legősibb eleme a család, amely egy pénzügyi, szolgáltatási és önellátási közösség, egyben a szociális-kulturális érzelmi biztonság alapeleme. A család mint a társadalmi integráció alapegysége, közösség vagy több közösség kapcsolatrendszerét jelenti, jellemzője az egymásrautaltság révén több generáción át fennálló gondoskodás egymásról, kölcsönös segítségnyújtás, ellátás biztosítása. A régmúltra visszatekintve évszázados hagyományok szerint a betegápolást elsősorban az otthoni élet nyugalmáért felelősséget viselő nők végezték. A nők társadalmi struktúrában megváltozott helye, általánossá váló munkavállalása miatt mára a betegről való gondoskodás és az otthoni betegápolás sok 
családban gazdátlanná vált. Az állam gondoskodó szerepén szocializálódott családok jelentős része számára az állammal szembeni elvárássá vált ezen funkció családon kívüli, társadalmi ellátása.

\subsection{Pénzügyi öngondoskodás}

A pénzügyi öngondoskodás szociális biztonságot nyújt a lakosság számára a betegség miatt kialakult nehéz helyzetekben. Két fő formája az előtakarékosság elvü egészségpénztárak, illetve a kockázatkezelt magánbiztosítások. Az egészségpénztárak adókedvezménnyel támogatott takarékoskodási lehetőséget biztosítanak az életszakaszok pénzügyi terheinek kiegyenlítésére, olcsó biztosítással kiegészítve. Ezen megtakarításokat a lakosság általában tervezhető kiadásokra fordítja, a váratlan kiadások terhének időbeli elnyújtására ritkán használják. Az egészségbiztositások feladata a nem tervezhető, nagyobb kiadások, a jövedelemvesztés elleni védelem kockázatközösségi bázison, céljuk a minőségi igények kielégítése. Az egészségpénztárakkal és egészségbiztositással nem kezelhető kiadások egyedüli fedezete a lakossági vagyon/jövedelem.

\subsection{Egészségügyi öngondoskodás}

Az egészségügyi öngondoskodás a betegek bevonását jelenti az egészségmegőrzési, betegségmegelőzési, gyógyítási tevékenységbe. Tudatosítja, hogy az egészséggel kapcsolatos döntéshozatal elsősorban az egyén, a beteg kezében van, ugyanis az egyén hoz döntést saját életmódjáról, betegségének menedzseléséről. Számos állapotváltozás megítélésében elsődleges észlelő maga a beteg. Az állapot életmódbeli faktorokkal való befolyásolásában szintén alapvető a beteg felelőssége. Hasonlóan kritikus a betegszerep a gyógyszeres terápia megvalósításában.

\section{BETEGEDUKÁCIÓ}

Az egyén egészséggel kapcsolatos döntéshozatali képességének kialakításához megfelelö informáltságra, motiváltságra van szükség. Ezen kulcsfontosságú funkció kialakításához nyitott egyének mellett egy információátadásra nyitott, megfelelő tudástranszfer technológiával rendelkező egészségügyi ellátó rendszerre is szükség van. Csak az egészségértés megfelelö szintjén lévő egyének lesznek képesek az egészségtudatos életvitelre. Hasonlóan, csak a kompetens betegektől várható el betegségük hatékony menedzselése.

Az információátadás során kritikus az információátadás módjának helyes megválasztása. Fontos, hogy a betegedukáció a beteg által könnyen befogadható nyelvezettel valósuljon meg, illeszkedve a beteg igényeihez. Törekedni kell arra, 
hogy az egészségügyi személyzet által közvetített információk alternatív, a beteg által könnyen elérhető információforrás révén is elérhetők legyenek. Az egyoldalú ismeretátadás mellett a betegedukáció igen fontos része az ismeretek visszakérdezése, megbeszélése, a beteg egyéni élethelyzetére adaptálása, és ezen lehetőségek megbeszélése. A szemléltetés, a közösen végrehajtott bemutató kezelések a hatékony betegedukáció fontos eszközei. Ha a beteg igényli, mélyebb, a betegsége megértését célzó ismereteket kell közölni. Ha erre nincs befogadó készség, akkor mindössze a teendők megbeszélésére kell szorítkozni. Mindenképpen fontos a páciens együttmüködését megnyerni, érdeklődését felkelteni, motiváltságát kivívni. A terápiahüség alapja egy bizalmi kapcsolat a beteg és kezelője/informátora (orvos, gyógyszerész, egészségügyi szakszemélyzet) között. Az edukációban a sorstársakat tömörítő betegszervezetek fontos szerepet játszhatnak.

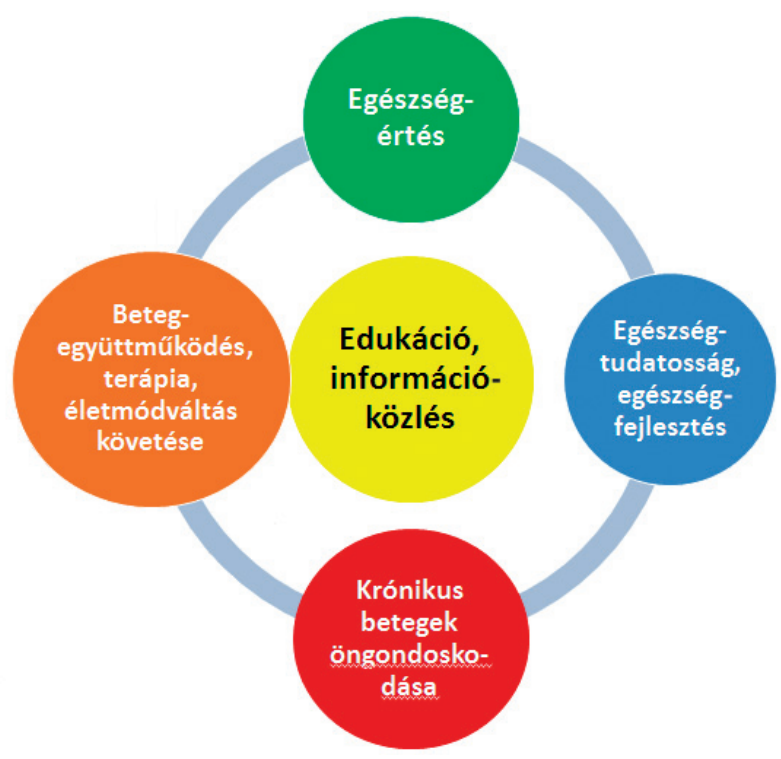

1. ábra. Az egészség-öngondoskodás szinterei

\subsection{Egészségértés}

Az egészségértés az egészséggel kapcsolatos alapvető információk és szolgáltatások elérésének, értelmezésének és megértésének képessége, valamint ezen információk és szolgáltatások felhasználásának kompetenciája az egészség fejlesztése érdekében. Az egészségmüveltség komponensei a tárgyi tudás az egészséggel és megelőzéssel kapcsolatban, a tudás alkalmazásának képessége és az itélőképesség az új információk helyes megítélésére. Az egészségértés vonatkozik az 
egészségügyi ellátással kapcsolatos kompetenciákra, a prevenciós ismeretekre és egészségfejlesztési felkészültségre.

Egy nemzetközi kutatási program folytatásaként 2015-ben a felnőtt magyar lakosság körében 1008 fö részvételével végeztek felmérést, és megállapították, hogy minden második embernek problémás az egészségértése Magyarországon, azaz nehezen képesek feldolgozni és alkalmazni az egészséggel, a betegséggel, valamint azok kezelésével kapcsolatos információkat. A hazai egészségértés tendenciájában hasonlít a más európai országokban meglévő trendekhez (például Ausztria), azonban mértéke valamivel alacsonyabb annál (Koltay-Kun, 2016).

A limitált egészségértés következményei egyaránt érintik a prevenció és a betegségek kezelésének területét. Alacsonyabb részvételi arány tapasztalható alacsony egészségértésű egyének esetén egészségfejlesztési, betegségfelismerési programokon. Ezen csoportoknak kockázatosabb az egészségügyi döntéshozataluk, például nagyobb arányban dohányoznak. Amennyiben krónikus beteggé válnak, betegségüket kevésbé tudatosan kezelik, adherenciájuk rosszabb. Ez növeli az ellátó rendszerre háruló költségeket. Ugyancsak jelentősek a költségkihatásai a rossz egészségértés miatt megnövekedett időtartamú és gyakoribb kórházi kezeléseknek, de magasabbak a morbiditási, illetve korai halálozási mutatói is (Visscher et al., 2018).

\subsection{Az egészségértés javításának eszközrendszere}

Az egészségértés egy átfogó nemzeti stratégia kidolgozása révén javítható, amely mindenki számára megfelelö hozzáférést biztosít az egészségügyi információkhoz. Kormányszintü és társadalomszintü problémakezelés szükséges, ami multiszektoriális feladat, túlmutat az egészségügy keretein, minden korosztályra kiterjedő hosszú távú programot képezve. Ezen stratégia alapja az oktatás, az egészségnevelés, amelynek kezdő lépéseit már egészen kisgyermekkortól, az óvodáktól alkalmazni kell. Az iskolákban a nemzeti alaptantervbe kell integrálni az egészségre nevelést. Az átadott információ minőségét és az információátadás módját, eszközeit úgy kell kialakítani, hogy életre szóló elköteleződés alakuljon ki az egészséges életmódhoz, betegségmegelőzéshez.

A felnőtt lakosság egészségműveltségi színtere a média, a tömegkommunikáció eszközrendszerével fejleszthető elsődlegesen. A közmédiában olyan egészség-népszerüsítő műsorok közvetítése szükséges, amelyek a lakosság széles rétegeihez eljutva képesek felkelteni ezen rétegek érdeklődését a téma iránt. Az információ eljuttatásában a nyomtatott sajtó mellett támaszkodni kell az internetes, mobileszközökön elérhető megoldásokra. Munkahelyi egészségügyi és jóléti programok ugyancsak hatékonyak lehetnek az egészséges életmód ösztönzésében, életviteli döntések javításában. 


\subsection{Információforrások, információközvetítés}

Egyértelmüen kijelenthető, hogy a lakosság tájékozódásának egyik legfontosabb eszköze ma az internet. A folyamatos internet-kapcsolattal rendelkező okostelefonok, számítógépek használata ma minden korosztály esetén szinte általános. A betegséggel kapcsolatban felkeresett első információforrás az internet.

Míg néhány évtizeddel ezelött a nyomtatott anyagokban, az írott sajtóban és a médiában ellenőrzött egészségügyi információk jelentek meg, mára az információk szakmai hitelessége egyáltalán nem garantált. Az internet terjedésével ellenőrizetlen, sok esetben körülírt piaci érdekeket szolgáló tartalmak tünnek fel. Az információk sokaságában komoly nehézséget okoz a megbízható információk kiszürése. A források kritikus értékelése, a hamis információk felismerésének képessége elsajátítható, de jelenleg a lakosság jelentős része nem rendelkezik ilyen típusú készséggel. A hiteles egészséginformációk biztosítása érdekében a megfelelő tartalmak minősítésére, jelölésére lenne szükség. A védjegyek, tanúsító bizonylatok megismertetése a lakossággal, épp úgy, mint ezen rendszerek menedzselése állami szerepvállalás nélkül ugyanakkor elképzelhetetlen. A tartalmak létrehozásának támogatására pályázati források biztosítása szükséges.

A betegek helyes tájékoztatását segíthetjük az áltartalmak elleni küzdelemmel, a tévinformációk, bizonytalan terápiák elleni fellépéssel is. Fontos lenne a káros tartalmak blokkolásának széles körủ médianyilvánossága a közösségi média eszköztárának igénybevételével. A téves információval való károkozás jogi következményeit feltétlenül ki kell dolgozni, és be kell építeni a jogrendünkbe (Kincses, 2016).

Napjainkban az internetes egészségügyi információszerzés mellett egyre inkább terjed a közösségi problémamegoldás, amikor a betegek nemcsak vakon keresnek információt az interneten, hanem online közösségekké szerveződve egy kapcsolati hálót hívnak segítségül. Az online betegközösségek tapasztalatot, információt osztanak meg egymás között, segítve a jobb informálódást betegségükkel kapcsolatban. Bár egyértelmüen hasznos és a betegeket támogató kapcsolatokról van szó, hazánkban az online betegközösségek népszerüsége a nyugati országokétól elmarad.

\section{PREVENCIÓ}

Az egészségértő személyek lesznek az alanyai az egészségükért tevő, betegségüket megelöző aktivitásoknak. A 2019. évi ENSZ-közgyülés határozata is felhívta a figyelmet arra, hogy az egészségügyi rendszerek kormányzati politikájában a prevenciót kell priorizálni megfelelő népegészségügyi programokkal, képzéssel, egészségkommunikációval és az egészségműveltség növelésével (UN, 2019). A preventív intézkedések bázisa az egyének egészséggel kapcsolatos ismereteinek az élet során való folyamatos bővítése. 


\section{KRÓNIKUS BETEGEK ÖNGONDOSKODÁS-TÁMOGATÁSA}

A krónikus betegségek gyakoriságának növekedése, a krónikus betegséggel való egyre hosszabb élettartam következtében ezen populáció ellátása emészti immár fel a teljes egészségügyi költségvetés $70-80 \%$-át a fejlett világ országaiban. A betegek terápiavezetésbe, betegségük kezelésébe való aktívabb bevonása, öngondoskodásuk támogatása akár 30 százalékkal is csökkentheti az ellátórendszerre nehezedő terhelést. Olyan megosztott ellátás kialakítására van szükség, amelynek nemcsak az egészségügy, hanem a beteg és a hozzátartozója is részese. A WHO 2002-ben állásfoglalást adott ki egy új típusú, a „beteggel konzultáló” ellátási rend szükségességéről, és ma már világszerte megfigyelhetőek azok a trendek, amelyek a megfelelően felkészített beteget tekintik saját maga elsődleges ellátójának (Pruitt et al., 2002). Az évtizedekig ellátást igénylő krónikus betegségek - magas vérnyomás, cukorbetegség, koszorúér-betegség stb. - akkor uralhatók hosszú távon, ha az ellátási folyamatba aktívan bevonjuk magát a beteget és környezetét.

\subsection{Az öngondoskodásra építő betegellátás és a klasszikus „nyugati típusú” betegellátás filozófiai különbsége}

A klasszikus nyugati orvoslás a betegségek patofiziológiai folyamatainak megértésére, a patofiziológiai folyamatok kémiai, biológiai és fizikai hatások általi befolyásolására épül, melyben az egyes gyógymódok alkalmazásáról való döntés az orvos kezében összpontosul. Az öngondoskodásra épülő rendszerek ezzel szemben a betegség menedzselésének elsődleges felelősévé magát a beteget teszik, az egészségügyi ellátórendszer feladata ezen rendszerben a betegdöntések szakértő támogatása lesz.

Egy 2002-es WHO állásfoglalás az élethossziglan tartó betegségek kezelése kapcsán a következő pontokat minősítette legfontosabbnak ezen új ellátási rend kialakításához (Pruitt et al., 2002):

- Paradigmaváltás szükséges az epizódalapú akut, illetve az élethosszig tartó állapotokat ellátó krónikus ellátási modellek között. Integrált ellátórendszert kell kialakítani, mely a beteg különböző szintű ellátási igényeit egy rendszerben kezeli.

- Az ellátás fókuszába a beteg és családja állítandó.

- A beteget a betegségével való megküzdésben saját környezetében kell támogatni, ki kell lépni az ellátó intézet falai közül.

- Az új ellátási modellhez anyagi és humán erőforrásokat kell biztosítani.

- A szakmapolitikai környezetet az öngondoskodásra épülö rendszer szerint kell átalakítani.

- Biztosítani kell a szektorsemlegességet az öngondoskodás támogatási folyamatokban.

- Súlyt kell fektetni a megelőzésre a már kialakult betegségek ellátása mellett. 


\subsection{A krónikus állapot öngondoskodás-támogatás szintjei}

A krónikus állapottal élő betegek öngondoskodás-támogatásánál a következő szintek kezelendők:

- Az egyének szintje, a beteg informálttá, motiválttá, döntésképessé tételével.

- Az intézmények szintje, a beteg aktív bevonására építő betegutak megszervezésével, az öngondoskodás támogatás tárgyi feltételeinek megteremtésével.

- Nemzeti szint, az öngondoskodás kérdésének megjelenítésével valamennyi egészségügyi szakember képzésében, az ellátó struktúra átalakításával, az új struktúra megfelelő finanszírozási ösztönzőinek kialakításával.

\subsection{Szükséges betegkészségek az eredményes öngondoskodáshoz}

Ahhoz, hogy bárki hatékonyan tudjon gondoskodni betegsége vezetéséröl a következő képességekkel kell rendelkeznie:

- betegsége és a betegség kezelési elveinek ismerete;

- az egészségügyi ellátókkal partnerségben egyeztetett kezelési terv elfogadása;

- életmód-módosítás a rizikófaktorok mérséklésére;

- a fiziológiai mérési eredmények és a tünetek monitorozási képessége;

- aktív döntés felvállalása;

- magabiztosság és énhatékonyság a támogató szolgálat elérésében.

Az állapot természetes lefolyását, az előforduló hirtelen állapotváltozásokat készségszinten kell ismerniük a betegeknek. Ez az alapja az eredményes orvos-beteg együttmüködésnek. Az öngondoskodás támogatásában ezért a hatékony ismeretanyag átadás alapvető.

A kezelés vezetésében való osztozás mindkét fél, azaz az orvos és a beteg oldaláról is változást jelent. Az orvosnak fel kell ajánlania ezt a megosztott felelősséget, a beteg elfogadása nélkül eredményes együttmüködés azonban elképzelhetetlen.

Az életmód átalakítása számos krónikus betegség esetében perdöntő a betegség kimenetele szempontjából. A klasszikus nyugati medicinában a közfinanszírozott egészségügyi ellátások köréből a szabadalmakkal körülbástyázott piaci termékek, mint például gyógyszerek, egészségügyi eszközök, sajnos aránytalanul nagyobb részt hasítanak ki maguknak, mint a szabadalmakkal nehezen védhető életmódi intervenciók. Az egészségügyi rendszereknek ezen lobbiérdekekkel torzított finanszírozási arányait az életmódi intervenciók pozitív diszkriminációjával kell ellensúlyozni.

A tünetek, paraméterek monitorozási képessége az állapotváltozások felismeréséhez elengedhetetlen. Az öngondoskodó betegeknek készségszinten kell értékelniük mérési eredményeiket, ismerve azon eltéréseket, melyeket saját ha- 
táskörükben - például gyógyszerelésük módosításával - kezelhetnek. Az öngondoskodási folyamat egyik legkritikusabb döntése annak megítélése, melyek azok a helyzetek, amelyeket önállóan menedzselhetnek, és mikor indokolt a döntés áthárítása az egészségügyi ellátó rendszerre. Hasonlóan kritikus a külső segítségkérés időfaktorának megítélése. Vannak ugyanis olyan folyamatok, melyekkel a következő munkanapon vagy néhány munkanapon belül elegendő az egészségügyi ellátórendszerhez fordulni, más esetekben - például egy érelzáródás esetén - viszont néhány órás késlekedés már visszafordíthatatlan egészségkárosodást eredményez.

\subsection{Szükséges készségek az ellátók oldalán az eredményes öngondoskodási rendszer kialakításához}

Ahogy a beteg oldalán, úgy az egészségügyi ellátók oldalán is új készségek kialakítása szükséges a betegek öngondoskodására építő rendszerek kialakításához. A szükséges ellátói készségek:

- a betegek önellátó képességének értékelése;

- betegek motiválása;

- életmód-módosítással befolyásolható a rizikófaktorok felismertetése, uralásának támogatása;

- megosztott ellátási rendszer kialakítása;

- hozzátartozók integrálása az ellátási folyamatba;

- a beteg monitorozásának képessége.

Az egyes betegek öngondoskodó képességének megítélése kulcsfontosságú, ez a rendszer azonban nem kellően kiforrott. Az öngondoskodó képesség megítélésére az egyszerü bináris (igen/nem) válaszrendszer helyett skálázott válaszrendszert célszerü kialakítani, mely kiterjed azon peremfeltételekre is, melyek teljesülése esetén a beteg képes meghatározott szintü öngondoskodásra. Ilyen peremfeltétel lehet például családtag vagy segítő szolgálat napi rendszerességü közremüködése az önellátás folyamatában.

A betegségükben öngondoskodásra motivált betegek a tájékozott betegekből lesznek, ezért a motiválás alapja a tudástranszfer az ellátó rendszer és a beteg között.

Valamennyi betegviselkedésre ható technikában kulcsszerepet játszik a beteg életmódjának átalakítása, ennek részeként a számtalan krónikus betegség alapjául szolgáló étkezési szokások átalakítása, illetve fizikailag aktív életmód kialakítása.

A hozzátartozó integrálása az ellátási láncba önellátásra képtelen személyeknél magától értetődő, de hasonlóan kulcsfontosságú lehet a fizikai és szellemi képességeikben hanyatló időskorúaknál. Tekintetbe kell vennünk azt is, hogy például a magyar társadalmi normák mellett a táplálkozási rend kialakítása jellemzően a családok női tagjának kezében van, ezért például a középkorú férfiak diétás 
gyakorlatának sikeres átalakítása sok esetben csak ezen partnerek bevonásával valósítható meg.

A krónikus állapot változásait nem elég, ha csak a beteg képes leképezni, a kezelést felügyelő orvosnak is rendelkeznie kell megfelelő technológiával arra, hogy a betege öngondoskodásának sikerességét, illetve esetleges kudarcait meg tudja ítélni. Ezt szolgálhatják különböző betegnaplók (vérnyomásnapló, vércukornapló, táplálkozási napló, tréningnapló), de az információtechnológia ezen támogatások digitális platformra - például mobiltelefon, tablet - vitelével ideális megoldást nyújt az igényekhez alkalmazható, időben szabadon skálázható távfelügyelet megvalósítására. Fontos filozófiai kérdés, hogy ilyen esetben a naplózás elsődleges célja, hogy a beteg önmaga át tudja tekinteni adatait, meg tudjon gyöződni erőfeszítései sikeréről. Másodlagos - ennek ellenére nem elhanyagolható funkció az egészségügyi személyzet távoli hozzáférése a monitorozott adatokhoz, majd az adatok áttekintésével a beteg segítése a megfelelő, önálló döntési gyakorlat kialakításában.

\subsection{Beteg-együttmüködés (adherencia)}

A betegek egészségügyi kompetenciái óriási szerepet játszanak a terápiában és életmódváltásban való együttmüködésben. Az orvosi utasításoknak megfelelés, a terápia követése (compliance) vagy még inkább az adherencia, azaz az egyén egészségügyi szakemberrel egyeztetett ajánlásoknak megfelelő viselkedése, partnersége a gyógyszerszedés, diéta és az életmódváltás területén, a terápia sikerének kulcsa. Felmérések szerint a nagy betegszámú krónikus betegségek esetén a hazai adherenciaadatok a nemzetközi adatoknál rosszabbak. Egy OEP NEAK (Országos Egészségbiztosítási Pénztár/Nemzeti Egészségbiztosítási Alapkezelö) finanszírozási adatok alapján készült vizsgálat alapján egy évvel a kezelés megkezdését követően - kéthavi gyógyszerkihagyást tolerálva - a 2-es típusú cukorbetegség kezelésében $50 \%$ a terápiakövetés, a csontritkulás gyógyszereinél $32 \%$, a benignus prosztata hiperplázia, valamint a lipidszintesökkentő gyógyszerek alkalmazása esetén pedig mindössze 22\% (Dóczy-Mészáros, 2013). Az elmaradó terápiás eredmények jelentős többletterhet okoznak, nő a rehospitalizáció aránya (5-10\%), romlik a betegek életminősége, életkilátása.

A beteg-együttmüködésben szerepet játszanak a betegtől függő tényezők, mint a beteg attitüdje, motiváltsága, feledékenysége, ismereteinek hiánya, a mellékhatásoktól való félelem vagy a kezelés szükségességének el nem fogadása. Az adherencia azonban ennél komplexebb. Társadalmi-gazdasági tényezők, szociológiai, szociodemográfiai szempontok, az egészségügyi ellátás szervezettsége, a betegoktatási kapacitás, a várólisták és a terápiával kapcsolatos tényezők, mint a kezelés komplexitása, mellékhatások, állapotjavulás észlelése is jelentősen befolyásolják a betegek terápiahüségét. 
A beteg-együttműködés javítása jelentős egészségnyereséget és költségmegtakarítást hozhat. Az adherencia javítása érdekében több szinten van szükség intézkedésekre, az orvos, a beteg, a gyógyszeres kezelés és az egészségügyi ellátórendszer szintjén. Az egészségügyi rendszer a monitorozó rendszerek fejlesztésével és az egészségügyi szolgáltatók együttműködésének javításával járulhat hozzá az adherencia fejlesztéséhez. Felhasználóbarát, a gyógyszeres terápiát egyszerüsítő gyógyszerkészítmények (például egytablettás kombinációk) ugyancsak segíthetik a jobb terápiahüséget. A betegtájékoztatás javítása, hatékonyabb orvosi tanácsadás, a szakellátókkal, gyógyszerészekkel, centrumokkal, betegszervezetekkel való szorosabb együttmüködés kialakítása is kedvező hatással van a beteg-együttmüködésre.

\subsection{Betegszervezetek szerepe az öngondoskodás megszervezésében}

Az egészségügyi információ beteg által történő dekódolása és annak végrehajtása kulcsfontosságú valamennyi, de különösen a krónikus betegségek kimenetelében. Milliárdokban mérhető költségek és megélhető életévek mennek kárba amiatt, hogy a beteg nem tudja, nem érti, vagy esetleg nem akarja mindazt megtenni, ami a maximális egészségnyereség eléréséhez adott betegségtípusban számára szükséges lenne. Bármennyit költhetünk egészségügyi programokra, gyógyszerekre, a sikeres terápia kulcsa a krónikus betegségekben részben vagy egészben a beteg kezében van. Az ellátó intézmények falain kívül a beteg szürke zónába kerül. Mindaz, amit tesz, vagy nem tesz, láthatatlan az egészségügyi ellátórendszer számára, az döntően az informáltságán, egészségértésén és környezetén múlik. A krónikus betegek öngondoskodási folyamatában felértékelődnek a betegszervezetek, melyek tapasztalt szakértőikkel, sorstárs-beteg segítőkkel igen sokat javíthatnak a komplex ellátási folyamat hatékonyságán. A betegszervezetek a betegségek kezelését és betegjogot támogató non-profit szervezetek. Elsődleges céljuk, hogy a betegeket közösségbe illesztve motiválttá, képzetté tegyék, javítsák a terápiahüséget, illetve népszerüsítsék az egészséges életmódmintákat. A betegszervezetek a betegek és az orvosi ellátás között hivatottak a híd szerepét betölteni. Kétirányú tolmácsként közvetíthetik a szakma elvárásait a betegek nyelvén a betegek felé, ugyanakkor az érintett csoport igényeit, problémáit a szakma felé (Grózli, 2019). Az egyértelmúen hiteles információk közvetítése kihasználja a betegek közötti kommunikációt, mivel a betegséggel eredményesen megbirkózó sorstársak szerepe felbecsülhetetlen. A betegszervezeti közösségeket gyakran különböző programok, világnapok, világjátékok, sportesemények stb. is erősítik. A betegszervezetek munkatársai a leggyakrabban a betegségben érintettek vagy alkalmi, laikus önkéntesek. A szervezetek finanszírozása, fenntarthatósága nem megoldott, jellemzően alkalmi támogatásokból, adományokból, legtöbbször a közremüködők önkéntes munkájával folytatják tevékenységüket. A betegszerve- 
zetek által elérhető legtöbb támogatás célzott programokra szól, így a szervezetek müködési költségeinek előteremtése állandó feszültségforrást képez, csökkentve ezáltal a tényleges tevékenységre fordítható energiát. Mivel a betegszervezetek edukációs tevékenysége és közösségformáló ereje a gyógyító munka integráns része, fontos lenne fenntarthatóságuk érdekében gazdálkodásukat biztos pénzügyi alapokra helyezni. Törekedni kell arra, hogy életpályamodellként is vonzó legyen a betegszervezetekben végzett szakszerü segítö munka.

\subsection{Gyógyszerészi gondozás}

A gyógyszerészi gondozás a betegek öngondoskodását, gyógyszerhasználatát segitő és az egészségmegőrzést támogató gyógyszerészi tevékenység, amelynek szakmai és jogi keretei hazánkban 2008-ban jöttek létre. A gyógyszertárak - Magyarországon jogi értelmezés szerint is - az egészségügyi alapellátási rendszer intézményei, melyek a betegek számára a legkönnyebben elérhetők. Becslések szerint a napi 10-12 órás nyitvatartás során 600000 lakos fordul meg a gyógyszertárakban, ami kiváló lehetőséget kínál az egészségmủveltség, a felelös egészségügyi öngondoskodás hiteles közvetítésére. Különösen a kistelepüléseken van meg annak a lehetősége, hogy a gyógyszerész élethosszig nyomon követhesse a páciensét, de hasonló szoros gyógyszerész-beteg kontaktusok városi gyógyszertárakban is kialakulnak. Ezek a kapcsolatok lehetőséget adnak arra, hogy a gyógyszerész átlássa a beteg teljes gyógyszerelését, valamint az egyéb kiegészítő termékek (például étrend-kiegészítők) fogyasztását. Amenynyiben a gyógyszerész és a beteg között kialakul a megfelelő bizalmi kapcsolat, a köztük folyó kommunikáció révén fény derülhet gyógyszerelési hibákra, eloszlathatók az öngyógyítással kapcsolatos tévhitek, és a gyógyszerész segítheti a beteget gyógyszerszedésének folyamatos feljegyzésében. A gyógyszerészek gondozási tevékenységének támogatására a Gyógyszerészi Gondozás Szakmai Bizottság protokollokat dolgoz ki; már rendelkezésre állnak a metabolikus szindróma, asztma, BPH, COPD, derékfájás kezelésére vonatkozó és várandósgondozási irányelvek.

A gyógyszertárak népegészségügyi tanácsadási szerepet is betöltenek, az utóbbi időben egyre intenzívebb a feladatvállalásuk népegészségügyi programokban, mint például az influenzaoltás népszerüsítése, a vakcinálás támogatása, a dohányzásról való leszoktatás, az allergiaprogram, a vastagbélszürési program vagy az étrend-kiegészítőkkel kapcsolatos intézkedések. A jól múködő gyógyszerészi gondozási tevékenység csökkentheti a gyógyszerekkel kapcsolatos ártalmakat és a hospitalizációt, akár 10\%-os mértékben is. Enyhítheti az idősödő háziorvosi kar és a sürgősségi osztályok túlterheltsége miatti problémákat azáltal, hogy szerepet vállal különféle tesztek elvégzésében, szürőprogramokban, és életmód-tanácsadást végez. 
Az eltelt évtizedekben a gyógyszerészeti szakmai szervezetek folyamatosan munkálkodtak a lehetséges feladatokra vonatkozó standardok széles körü megismertetésén, a napi gyakorlat ez irányú harmonizálásán. A jobb hatékonyság érdekében javítandó a gyógyszerészi gondozás szervezettsége, kívánatos lenne a patikák specializációja egyes gondozási szerepekre, vagy ilyen egészségügyi centrumok létrehozása. Sajnos a gyógyszerészi gondozás ma a gyógyszerészek önként vállalt tevékenysége, tényleges erkölcsi és anyagi elismerése még nem megoldott, illetve társadalmi jelentősége, haszna nem felismert, és nem kellően kihasznált.

\subsection{A telemedicina mint az öngondoskodást támogató eszköz}

A krónikus betegek öngondoskodása kapcsán szót kell ejtenünk a telemedicina kínálta lehetőségekről. A telemedicina távközlési és informatikai technológiákat alkalmaz az egészségügyi ellátás javítása érdekében. Olyan centrális és egységes informatikai megoldást biztosít, amely hatékonyan összeköti a betegeket a monitorozó egészségügyi okoseszközök, illetve klinikai telemedicina müszerek révén az intézményi informatikai rendszerekkel. Az orvos ezáltal automatikus visszajelzést kaphat a beteg státuszáról, gyógyszereléséről, az alkalmazott terápia hatékonyságáról. A beteg intenzívebben kerül bevonásra saját terápiájának megítélésébe, vezetésébe, ami javíthatja együttmüködési készségét, motivációját, úgy a gyógyszerszedés, mint a diéta vagy a fizikai aktivitás vonatkozásában (Győrffy, 2019). A digitális eszközök elterjesztéséhez, széles körü bevezetéséhez komplex edukációra van szükség mind az orvosok, mind a betegek részére. Mivel az információs technológia folyamatosan csökkenő költségü ágazat, alkalmazásának szélesítése a digitalizáció állami támogatásával - a nyugat-európai országokhoz hasonlóan - Magyarországon is indokolt.

\section{KÖVETKEZTETÉSEK}

A jövő egészségügyi ellátásában a passzív betegszerepen alapuló orvos-beteg kapcsolatot a kölcsönösségen, partnerségen alapuló viszonynak kell felváltania. A beteg úgy tud aktív szerepet játszani egészségének, betegségének menedzselésében, ha megfelelöen tájékozott, és felkészült erre a szerepre. Az egészségértés fejlesztését az iskolákban kell elindítani, majd az élethosszig tartó tanulás részévé kell tenni. A krónikus betegségekben szenvedők növekvő ellátási igényének kezelésére speciális öngondoskodást támogató rendszerek életre hívása szükséges, melyek megfelelően összehangoltak, és integrálódnak az ellátó struktúrába. Hazánkban is egységes keretrendszert kell kiépíteni, mely megteremti a betegek befogadóképességéhez igazított betegedukáció feltételeit, kialakítja a krónikus 
betegségekben fontos életmódváltás-támogatás hatásos technikáit. Az öngondoskodás megteremtésében felértékelődnek a betegszervezetek és a nem orvosi diplomás egészségügyi szakemberek (gyógyszerészek, MSC/BSC-diplomás ápolók, dietetikusok, gyógytornászok). Építeni kell a rohamosan fejlődő infokommunikációs technológiák alkalmazására, a betegadatokon alapuló intelligens döntéstámogató megoldások alkalmazására, illetve a távkonzultációs lehetőségek jobb kihasználására.

\section{IRODALOM}

Dóczy V. - Mészáros Á. (2013): Beteg-együttműködés, módszertani kérdések és hazai vizsgálatok. Acta Pharmaceutica Hungarica, 83, 13-27. https://bit.ly/35YUbL0

Grózli Cs. (2019): Rajtad is múlik! Képzett beteg edukációs program tapasztalatai szervátültetetteknél. IME - Interdiszciplinális Magyar Egészségügy, 18, 5, 32-35.

Győrffy Zs. (2019): E-páciensek és digitális gyógyítóik. Magyar Tudomány, 180, 10, 1471-1485. https://mersz.hu/hivatkozas/matud f30146\#matud f30146

Kincses Gy. (2016): Lesznek-e útjelzők az információk Bábelében? Interdiszciplináris Magyar Egészségügy, 15, 7, 7-10.

Koltay J. A. - Kun E. (2016): A magyarországi egészségértés nemzetközi összehasonlításban. Egészségfejlesztés, 57, 3, 3-20. http://folyoirat.nefi.hu/index.php?journal=Egeszsegfejlesztes\&page $=$ article \&op $=$ download\&path $\% 5 \mathrm{~B} \% 5 \mathrm{D}=62 \&$ path $\% 5 \mathrm{~B} \% 5 \mathrm{D}=\mathrm{pdf}$

Pruitt, S. - Annandale, S. - Epping-Jordan, J. et al. (2002): Innovative Care for Chronic Conditions - Global Report [Internet]. Geneva, Switzerland: WHO, https:/www.who.int/chp/knowledge/publications/icccglobalreport.pdf

UN (2019): UN General Assembly 18 October 2019, Seventy-fourth Session Global Health and Foreign Policy. Political Declaration of the High-level Meeting on Universal Health Coverage. A/RES/74/2. https://undocs.org/en/A/RES/74/2

Visscher, B. B. - Steunenberg, B. - Heijmans, M. et al. (2018): Evidence on the Effectiveness of Health Literacy Interventions in the EU: A Systematic Review. BMC Public Health, 18, 1, Article number 1414. https://bmcpublichealth.biomedcentral.com/articles/10.1186/s12889-0186331-7 